\title{
INTERCOMPARISON OF METHODS TO ESTIMATE BLACK CARBON EMISSIONS FROM COOKSTOVES
}

Candela de la Sota, ${ }^{+1}$ Moustapha Kane, ${ }^{3}$ Javier Mazorra, ${ }^{1}$ Julio Lumbreras,${ }^{1}$ Issakha Youm, ${ }^{3}$ Mar Viana ${ }^{2}$

${ }^{1}$ Technical University of Madrid. José Gutiérrez Abascal, 2. 28006, Madrid, Spain.

${ }^{2}$ Institute for Environmental Assessment and Water Research, Spanish National Research Council (IDAEA-CSIC). Jordi Girona 18-26. 08034, Barcelona.

${ }^{3}$ Centre for Studies and Research on Renewable Energy (CERER) of the Cheikh Anta Diop University of Dakar(UCAD). Route du Service géographique (HB-87) x HB-478, Hann Bel-Air, 476 Dakar, Senegal.

*corresponding author: candela.delasota@upm.es. +34 699284386

\section{DESCRIPTION OF SUPPORTING INFORMATION}

The supporting information contains images showing the material used in the study: Laboratory Emission Monitoring System (LEMS), schematic of the gravimetric system of the LEMS, Nexleaf BC reference card and quartz and glass fibre filters. It also provides complete results of the ANOVA test performed in the study.

\section{ABSTRACT}

Black carbon is the second largest contributor to climate change and also poses risks to human health. Despite the need for black carbon (BC) emissions estimates from residential biomass burning for cooking, quantitative data are still scarce. This scarcity is mainly due to the scattered location of the stoves, as well as relatively costly and complex analytical methods available. Two low cost and easy-to-use optical methods, a cell-phone based system and smoke stain reflectometry, where compared to elemental carbon (EC) concentrations by the Sunset OCEC Analyzer (TOT)". The 
three techniques were challenged with different aerosol types (urban and biomass cookstoves), and different filter substrates (quartz and glass fibre). A good agreement was observed between the two low cost techniques and the reference system for the aerosol types and concentrations assessed, although the relationship was statistically different for each type of aerosol. The quantification of correction factors with respect to the reference method for the specific conditions under study is essential with either of the low-cost techniques. BC measurements from the cell-phone system and the reflectometer were moderately affected by the filter substrate. The easy use of the cellphone based system may allow engaging cookstove users in the data collection process, increasing the amount and frequency of data collection which may, otherwise, not be feasible in resourced constrained locations. This would help to raise public awareness about environmental and health issues related to cookstoves.

Keywords: Biofuel emissions; Elemental carbon; Cellphone sensing; Lower-middleincome countries; Emission inventories.

\section{INTRODUCTION}

Black carbon (BC) is a type of primary carbonaceous aerosol emitted during the incomplete combustion of fossil fuels, wood and other forms of biomass (Ahmed et al., 2009). It is composed of sub micrometer particles that have an unique combination of physical properties (Bond et al., 2013) such as a strong absorption of visible light and a high resistance to chemical transformation (Petzold et al., 2013).

$\mathrm{BC}$ is a short-lived climate pollutant that only remains in the atmosphere a few days (Pachauri and Reisinger, 2007). It has been described as the second most important component of global warming after $\mathrm{CO}_{2}$ in terms of direct forcing (Jacobson, 2000). It causes warming of the atmosphere through a number of different processes (United Nations Environment Programme, 2011). When suspended, it absorbs solar 
radiation and influences cloud formation. When deposited on snow and ice, it darkens their surface, which accelerates heat absorption and ice melting (Ramanathan and Carmichael, 2008). Moreover, BC is an important component of particulate air pollution, and it is associated with adverse health effects and premature death (WHO and Scovronik, 2015).

Twenty-five percent of the total global BC emissions is attributed to emissions of BC from residential biomass burning (Lamarque et al., 2010). Biomass is used worldwide by more than two billion people that depend on wood, crop residue, and dung as their primary energy source for domestic needs such as heating and cooking (Roden et al., 2009). Thus, emissions of this climate and health-related pollutant resulting from solid biomass burning in traditional cookstoves is a global concern (Arora and Jain, 2015). Moreover, its measurement is critical to understand and evaluate the effectiveness of BC mitigation actions, such as the introduction of cleaner and more efficient cooking technologies, also known as improved cookstoves.

The WHO indoor air quality guidelines for household fuel combustion (World Health Organization, 2014) provide recommendations to public health policy-makers and specialists working on energy, environmental and other issues to reduce household air pollution. They recognise that incorporating protocols, facilities and technical capacity for carrying out testing in parts of the world where this is most needed, is critical for their implementation. WHO also identifies key research needs such as emission testing to determine impacts of improved household energy technologies and clean fuels under real life and the relevance of studying the role of black carbon.

However, BC emissions from cookstoves have been less characterized than those from other common sources, such as diesel engines (Johnson et al., 2008). In recent years, the number of studies measuring biofuel combustion emissions increased (Zhang et al., 2000; MacCarty et al., 2008; Fan and Zhang, 2001; Bhattacharya et al., 2002) but only a limited number of them analyzed BC cookstove emissions using 
optical and thermal-optical methods (Johnson et al., 2008; Ramanathan et al., 2011; Patange et al., 2015; Rehman et al., 2011; Venkataraman et al., 2005).

The scarcity of studies on biofuel emissions from cookstoves and, more specifically, on BC emissions, is due to the complexity related to measuring emissions from such a heterogeneous and diverse activity (MacCarty et al., 2008). In general, pollutant measurements (including BC) in rural and resource-constrained areas are limited by the lack of adequate instrumentation, power supply and reproducible environmental conditions. Other causes are the wide distribution and remote location of these stoves, as well as the relatively invasive and complex assessment methods available (Johnson et al., 2008). Very often, BC measurement techniques pose a challenge in terms of their high upfront cost and level of technical expertise required for operating them (Ramanathan et al., 2011).

In this work, the performance of two low-cost and easy to use methods for BC estimation was assessed: reflectometry, and a cell-phone-based system (in general, any camera-based system). These methods have the potential to be used for studies in resource-constrained locations due to their low cost, portability and low technical requirements. Moreover, their easy use can open up possibilities of involving cookstove users in the data collection process, which would result in awareness raising on this topic (Nelms et al., 2016). Although there are several examples of citizen science projects (Castell et al., 2015; Kaufman et al., 2014; among others), this approach has rarely been used in cookstoves studies. The increased use of mobile phones can bridge the gap in resource constrained locations, where other infrastructure is lacking.

The performance of the lower-cost methods was assessed by comparison with the European reference method for EC quantification on filter samples (CEN TC264WG35), thermo-optical transmission (TOT) analysis (Cavalli et al., 2010) which, due to its relative complexity and cost, is in general not applicable for field work in situations with limited means. 
It is essential to note that the three techniques measure different parameters: while the reference method determines EC concentrations, the cell-phone-based system estimates $B C$ and the reflectometer measures reflectance. The concepts of BC and EC are not equivalent (Petzold et al., 2013), so the differences must be taken into account during the comparison between methods.

The results obtained with the three techniques were compared for different aerosol types and loads, as well as for different filter substrates.

The aim of this work was to assess the performance of the reflectometer and cellphone optical analysis when compared to the thermal-optical transmission (TOT) analyzer. If proved to be comparable within a given uncertainty range, these methods could be recommended as lower-cost tools for estimation of $\mathrm{BC}$ from cookstove emissions in resource-constrained locations.

\section{EXPERIMENTAL METHODS}

\section{Sample collection.}

Aerosol samples were collected in two locations, Dakar (Senegal) and Barcelona (Spain). Samples were collected to obtain a range of BC and EC loads (from low to high) and to assess the influence of different aerosol types on measured BC and EC concentrations. This enables a more robust comparison of the three techniques (Ahmed et al., 2009). Samples were collected on quartz fibre filters (Pallflex, tissuquartz, 2500 QAT-UP) and glass fibre filters (Hi-Q environmental products, FPAE102, $0.3 \mu \mathrm{m}$ aerodynamic equivalent diameter).

In Dakar, samples were collected at the Research and Studies Centre on Renewable Energies of the University of Dakar (CERER, UCAD) using a Laboratory Emissions Monitoring System (LEMS), developed by the Aprovecho Research Center (ARC) (see photos in supporting information). This system was 
designed to sample cookstove emissions after dilution. In this way, the aerosol concentrations sampled may be considered as a good approximation of indoor emissions in a typical rural household in Senegal during the cooking hours. In Barcelona, on the other hand, aerosol concentrations were sampled in outdoor air at an urban background air quality monitoring station located in the vicinity of traffic emissions (IDAEA-CSIC Station).

Both types of samples were representative of markedly different aerosol types: biomass burning aerosols for indoor air quality in households using solid fuels as primary source of energy in Senegal, and urban aerosol dominated mainly by traffic emissions, characteristic of ambient air in a typical European city, Barcelona. BC andEC concentrations were much lower in the Barcelona than in the Dakar samples.

In the LEMS in Senegal, the stove was placed under a hood structure which collects exhaust flows produced during the combustion. It has a gravimetric system to measure $\mathrm{PM}_{2.5}$ using filter-based sampling, which consists of a vacuum pump that draws a sample through a sample line and a critical orifice at a steady flow of 16.7 L/min. A cyclone particle separator was used so that $\mathrm{PM}_{2.5}$ was collected on a filter while the pump was switched on.

Filters for PM collection were regularly changed as they were quickly saturated with $\mathrm{PM}_{2.5}$. To solve this, the ARC designed a modification of the gravimetric system by adding a second sampling train in parallel with the gravimetric sampling train, with a lower flow rating of $3 \mathrm{~L} / \mathrm{min}$. This separate $\mathrm{BC}$ sample train allowed a simultaneous collection of $\mathrm{PM}_{2.5}$ and $\mathrm{BC}$ samples as well as the use of different types of filter media. The Water Boiling Test (WBT) protocol (version 4.2.3) was applied. The WBT is a standardized test, commonly used in the laboratory, which is a simplified simulation of the cooking process intending to measure how efficiently a stove uses fuel to heat water in a cooking pot and the emissions produced while cooking.(The Water Boiling Test. Version 4.2.3. Cookstove Emissions and Efficiency in a Controlled Laboratory 
Setting, 2014). In this test, 5 liters of water are brought to boil (cold start phase) and then simmered for 45 min (simmer phase).

In Barcelona, ambient air $\mathrm{PM}_{2.5}$ samples were collected by means of a MCV CAV-A (MCV S.A.) high-volume sampler $\left(30 \mathrm{~m}^{3} / \mathrm{h}\right)$. This type of sampler is certified to be equivalent to the EU reference for $\mathrm{PM}_{2.5}$ monitoring. The sampler was located at the IDAEA-CSIC reference station $\left(41^{\circ} 23^{\prime} 14^{\prime \prime} \mathrm{N}, 02^{\circ} 06^{\prime} 56^{\prime \prime} \mathrm{E}\right)$. Samples were collected over 24hr periods.

In total, 102 quartz fibre filters and 81 glass fibre filters were collected in Senegal, and 222 quartz fibre filters were collected in Barcelona. Some of these samples were removed because $\mathrm{BC}$ deposition was below or above analytical limits of detection. Finally, 73 quartz fibre filters collected in Senegal and 76 in Barcelona were analysed with the three analytical methods, and 52 glass fibre filters sampled in Senegal were analysed with the cell-phone system and the reflectometer, given that glass fibre filters are not recommended for analysis by TOT. Glass fibre filters are generally preferred to quartz ones in resources-constrained areas due to their lower cost.

\section{Determination of BC and EC on filters.}

There are different methods to determine the concentration of BC/EC based on the chemical, physical and light absorption properties of the particles (Petzold et al., 2013). The optical methods quantify the light absorbing component of the particles, and are based on the fact that $\mathrm{BC}$ absorbs light due to its colour. The thermal-optical methods determine the quantity of graphitic-like elemental carbon (EC) based on its stability at high temperatures in an inert atmosphere. In this work, we used two optical filter-based techniques (reflectometry and cell-phone based system) and one thermaloptical transmission (TOT) filter-based technique, all of them offline. The latter determines $\mathrm{EC}$ concentrations, whereas the former two estimate $\mathrm{BC}$ concentrations. 
Cell-phone based system (Nexleaf). It is an optical technique in which a photograph of the filter is captured with a cell-phone or a camera and transmitted to a server where an algorithm compares the image (the colour of the filter) with a calibrated scale (see photos in supporting information). The BC load is estimated by measuring its reflectance in the red wavelength, based on the "blackness" of the photograph.

This system is easy to use, cheap and rapid and its performance was already assessed by its developers (Ramanathan et al., 2011; Patange et al., 2015). According to the manufacturer specifications, the measurement range is $5-25 \mu \mathrm{gC} / \mathrm{cm}^{2}$, with an accuracy of $20 \%$ (Ramanathan et al., 2011). It is important that the filter colours are not in the limits of the reference scale (too white or too black), and photos of the filters and optical reference cards need to be taken under relatively uniform lighting.

Within a citizen science approach, cookstove users may use the camera on their mobile phones to capture and transmit the images containing the filter and colour chart to the server, to automatically compute the daily BC concentrations for each household. This would only be possible if comparable sampling methods and durations are used, in order to allow for comparison of BC loadings $\left(\mu \mathrm{g} / \mathrm{cm}^{2}\right)$ between different users. The focus of such a citizen science approach would be air quality and health, and not climate studies (due to the lack of OC data).

Smoke stain reflectometer (Model 43D, Diffusion Systems Ltd.). The reflectometer is a non-destructive and portable system, commonly used to determine BC concentrations (Biswas et al., 2003; Begum et al., 2007; Downward et al., 2015). It has already been used in several cookstove BC emission studies (Johnson et al., 2008; Huboyo et al., 2009). A high-performance LED with maximum emission at 650 $\mathrm{nm}$ shines on the filter, and the reflected light is measured by a photo-sensitive element (Safo-Adu et al., 2014).

Then, the electrical response is amplified to produce a reflectance reading (RR). The darker the filter, the lower the amount of reflected light, in such a way that low RR 
values correspond to high $\mathrm{BC}$ loads and vice-versa. The reflectometer reads on a scale of 0 (black) to 100 (white), although $R R<10$ and $>90$ suffer from major uncertainty (Adeti, P.J, 2012). The manufacturer recommends the use of paper filters, although the use of other filter materials, such as in this study, is also possible (Biswas et al., 2003, Johnson et al., 2008; Huboyo et al., 2009; Salako, 2012).

Sunset Laboratory Carbon Analyzer. This instrument determines the elemental carbon (EC) content on quartz fibre filters by using a thermal-optical method. Carbonaceous aerosols are thermally desorbed from the filter substrate under an inert helium atmosphere followed by an oxidizing atmosphere, using controlled heating ramps. The carbon contained in the sample is detected as $\mathrm{CH}_{4}$ by a flame-ionization detector (Petzold et al., 2013) while organic (OC) and elemental (EC) carbon are discriminated by monitoring the optical transmittance through the filter sample. In this work, the EUSAAR2 thermal protocol was used (Cavalli et al., 2010). Even though differences have been reported with the use of different temperature protocols (EUSAAR2, NIOSH, IMPROVE) (Chow et al., 2004; Cavalli et al., 2010) these differences are systematic and may be corrected when comparing results from studies using different protocols for the same types of aerosols.

In this work, the thermal-optical analysis was considered as the reference system for comparison with the two lower-cost optical methods described above. This technique was recently established as the reference EU method for OC and EC quantification on filter samples by the CEN standardization working group WG35 (CENTC264-WG35).

\section{Method limitations.}

A number of limitations must be taken into account in this work:

a) Regarding the optical methods, the extent of filter loading can influence particle, thus biasing the results (EPA-450/R-12-001, 2012). 
b) When using the reflectometer, the device is in direct contact with the filter surface. This may lead to potential mass loss and/or cross contamination (Yan et al., 2011). The use of a teflon ring is recommended to protect the filter and mitigate potential impacts of contamination.

c) The dependence of aerosol absorption on different wavelengths. The reflectometer works in the visible spectrum, and therefore BC measurements may be affected by interference with other light absorbing components. In the cell-phone system, BC load is estimated by measuring its reflectance in the red wavelength, where interference of other light absorbing components, like organic carbon, should be small or within the instrument's uncertainty range (Ramanathan et al., 2011).

d) For all three methods, results are influenced by the chemical composition and emissions sources of the aerosol, filter loading and uniformity of the particle deposit (Watson et al., 2005). BC/EC measurements from biomass smoke may be more strongly affected than diesel engine samples, in part because of their higher levels of inorganic components and brown carbon (Novakov and Corrigan, 1995).

e) The methods assessed quantify BC and/or EC concentrations, but do not measure organic carbon $(\mathrm{OC})$. This should be considered a limitation from the point of view of climate studies, where both $\mathrm{OC}$ and EC data are needed to obtain a reasonable characterisation of aerosols warming and cooling implications. However, this should not be considered a limitation if the proposed methods are used for air quality and health effects studies.

\section{Technical requirements and features of the methods.}

In addition to the performance of the methods regarding their comparability with the reference, data quality and uncertainty of the measurements, the selection of a specific method for measuring $B C$ emissions from cookstoves should also consider technical requirements. Table 1 includes the main parameters to be evaluated. 


\section{Statistical analysis}

The statistical program STATGRAPHICS (StatPoint Technologies, Inc., 2014) was used for data analysis. The relationship between the analytical methods was established using the coefficient of determination $\left(R^{2}\right)$ and an analysis of variance (ANOVA) was used to compare regression lines from the two types of aerosols. Further, the Wilcoxon signed-rank test (Woolson, 2008) a non-parametric test procedure for the analysis of matched-pair data, was conducted in order to assess the differences between results from the cell-phone and the TOT system.

\section{RESULTS AND DISCUSSION}

BC analysis by the cell-phone system compared with EC by thermo-optical analysis (TOT).

Figure 1 presents the results for BC load using quartz fibre filters with two different types of aerosols: biomass aerosols from cookstove emissions, and urban aerosols. For both types of aerosols, a high degree of correlation between the cellphone and TOT methods may be observed $\left(R^{2}>0.80\right)$.

For biomass aerosol samples, linear regression resulted in a slope of 1.35 with a correlation coefficient $\left(R^{2}\right)$ equal to $0.84(p<0.05)$, after exclusion of two outliers. In the case of urban aerosols, the correlation was slightly higher $\left(R^{2}=0.88\right)$, with a regression line slope $=0.71(p<0.05)$. The systematic error of the methods and the experimental error may explain the intercept of the regression curve, although the value is very close to zero. These results show that, for each different type of aerosol, the $\mathrm{BC}$ concentrations measured with the optical cell-phone method are well correlated with the reference EC concentration range shown in Figure $1\left(2-20 \mu \mathrm{g} / \mathrm{cm}^{2}\right)$. 
This good correlation would suggest that, after determining the slope of the linear regression for the target aerosol under study, which should be done locally and for each study case, the optical cell-phone method could be considered an option for the estimation of $\mathrm{BC}$ concentrations in cookstove studies. It is essential to note that an initial calibration of the method with a reference instrument and using EC from local aerosol samples as reference would be an absolute pre-requisite for this. Any study attempting to use these methods must previously calibrate them using the same type of aerosol (under the same real-world conditions) as will be targeted.

The application of an analysis of variance, ANOVA, (see supporting information for complete results) showed that the slopes obtained from cookstove and urban aerosols were statistically different, with a confidence level of $95 \%$. The different slopes obtained result from differences in the physical and chemical composition of the aerosols studied, mainly their mass absorption cross-section (MAC; Zanatta et al., 2016). The MAC is defined as the light absorption coefficient $\left(\sigma_{\text {ap }}\right)$ divided by elemental carbon mass concentration $\left(\mathrm{m}_{\mathrm{EC}}\right)$, and expressed in units of $\mathrm{m}^{2} / \mathrm{g}$ (Zanatta et al., 2016). Different types of aerosols are characterised by different MAC values, especially when dealing with the combustion of different fuels (Watson et al., 2005; Ahmed et al., 2009). In particular, wood burning emits large amounts of organic gases along with BC aerosols during smoldering (WHO and Scovronik, 2015; Bond et al., 2007; Petzold et al., 2013). The coating of non-absorbing organic (OC) layers on BC particles enhances the absorption (increases the MAC) (Zanatta et al., 2016), resulting in higher BC loads by optical method (Ahmed et al., 2009). Furthermore, light-absorbing organic matter, also known as brown carbon (Andreae and Gelencsér, 2006), may have influenced BC measurements. As a reference, in the present study urban aerosol samples had OC loadings between 5.6 and $22.9 \mu \mathrm{g} / \mathrm{cm}^{2}$, and an average OC/EC of $2.45( \pm 1.14)$ (for a representative subset of samples). For biomass aerosols, OC filters loadings were 3.8 53.7, and the average OC/EC was $2.61( \pm 1.78)$. Thus, OC/EC ratios were similar for both types of aerosols in this study, suggesting that the relative OC load did not explain 
the differences in response to optical methods for the urban and biomass aerosols. However, one very relevant limitation is that a number of the biomass aerosol filters were not preserved cold during transport and until analysis, which may have accounted for probable OC losses.

Studies have shown that biomass aerosols have higher light absorption than traffic-generated particles (Salako, 2012), while others had shown an opposite trend (Jeong et al., 2004). The discrepancies could be due to the complex interaction of physical aerosol properties and the filter matrix (Andreae and Gelencsér, 2006).

Another factor possibly affecting the different slopes obtained in Figure 1 could be particle size, given that the cookstove emissions were fresh particles directly emitted by the source whereas the urban particles underwent a certain ageing during transport from the source (vehicular traffic) to the urban background station. However, further studies would be necessary to evaluate the potential influence of particle size.

To assess the statistical differences between both methods as a function of the aerosol load, the Wilcoxon signed-rank test, a non-parametric statistical hypothesis test recommended for small sample sizes, was applied. Differences were quantified by calculating the absolute relative differences between the cell-phone and the TOT results, for each data point and then averaged (in absolute value) across samples. An analysis of the differences between the TOT and the cell-phone systems at different loadings was carried out in order to understand the potential influence of the filter loading on the optical methods response (Weingartner et al., 2003).

The Wilcoxon signed-rank test indicated that results from both methodologies were, with $95 \%$ significance level, slightly different except for urban aerosols with low EC load. Table 2 shows that these differences were not large, and that they varied with aerosol load: larger similarities were observed at higher aerosol loads (with decreasing relative differences, from $43 \%$ to $36 \%$ in cookstove aerosols, with increasing particle load for biomass aerosols, table 2). The only exception to this was observed for urban aerosols at low concentrations (non-statistically significant differences). This result 
highlights the overall need to take into account the aerosol load, as well as the aerosol type, when calibrating the cell-phone method.

Filter loading produces two effects on the optical methods response. On the one hand, the mass loading increases the absorption coefficient (Presser et al., 2014). At the same time, shadowing effects may occur on the filter surface with heavier filter mass loading, resulting in an apparent reduced optical path length through the filter (Weingartner et al., 2003; Presser et al., 2014) and leading to the underestimation of the measured optical signals with high filter loads.

In general, in this kind of studies (e.g., cookstove studies) measured concentrations remain within a given (high) concentration range. Therefore carrying out the calibrations proposed in this work, tailored to the specific aerosol under study and at the concentrations expected, should be feasible. In our study, because the differences are relatively small (between 36-43\%) one single correction equation is proposed.

Reflectance analysis by smoke stain reflectometer compared with EC by thermooptical analysis (TOT).

Data are already available in the literature correlating reflectance measurements with EC values (Adeti, P.J, 2012). However, due to the variability in carbonaceous aerosol levels and composition associated with different sources (Hinds, 1999), including fuel-stove combinations, local calibration for the specific type of aerosol under study of reflectance-based EC measurements is still necessary (Johnson et al., 2008).

By regressing the EC load $\left(\mu \mathrm{g} / \mathrm{cm}^{2}\right)$ against the reflectance values from the reflectometer two calculation equations were obtained $(p<0.05)$. After following a regression analysis, the best regression model to describe the relationship between RR values and EC was found to be a reciprocal lineal model. The equation to calculate EC from RR values determined with the reflectometer in the case of urban aerosol studied 
is $1 / R R=0.0034 E C+0.0116\left(R^{2}=0.9\right)$ and, in the case of biomass cookstove aerosol studied, $1 / R R=0.0081 E C-0.006\left(R^{2}=0.9\right)$. The results in Figure 2 show a clearly low dispersion of the data points, indicating a high accuracy in the estimation of EC using RR values.

"An external verification of the correlations summarized in table 3 would be recommended. In general, the calculation and subsequent testing of these correction coefficients against a reference system is recommended for each specific study, given that each specific population is affected by EC and BC emissions from emission processes, which determine the type of aerosol generated (Bond, 2004) and thus the correction coefficients. Statistical representativeness should also be taken into account."

\section{Analysis of filter substrate on BC and EC quantification.}

To evaluate the influence of the filter substrate on the performance of the optical methods evaluated in this study, 16 paired filters (quartz and glass fibre) were identically loaded using the double-filter system of the LEMS (see Methodology section). The BC load for each type of filter substrate was then analysed using reflectometry and cell-phone methods, the only two methods which are able to analyse both quartz and glass fibre filters. The comparison between filter substrates is especially relevant due to the significantly lower cost of glass fibre filters when compared to quartz fibre ones, in addition to their lower dependence on ambient humidity (for mass determination purposes by gravimetry. As a result, glass fibre filters are much more appropriate for resource-constrained sampling locations.

Figure 3 shows that optical BC measurements were moderately affected by the filter substrate. For identically-charged filters, reflectance values on glass fibre filters were $7 \%$ lower than for quartz fibre filters, with a significantly low dispersion of the data $\left(R^{2}=0.99\right)$. Regarding the cell-phone system results, the influence of the filter substrate tended to be larger and with an opposite trend with BC concentrations on glass fibre 
filters being approximately $12 \%$ higher than those determined on quartz fibre filters. Data dispersion, even if still low, was higher $\left(R^{2}=0.94\right)$ than by reflectometry.

There is visual evidence that filter characteristics are different. Glass fibre filters are matted, while quartz fibre are fibrous (see supporting information). Also, they have different pore size. Previous studies have explained that fibrous filters allow the particles to become partly or completely embedded (Bond et al., 1999).The penetration of particles into the filters causes multiple scattering within the filter (Presser et al., 2014; Davy et al., 2017) and may cause the filters to be more reflective for a given aerosol loading than if the particles were retained on their surface (Edwards et al., 1983). This occurs on matted filters, where the particles appear to be distributed discretely over the uneven topography of the matted surface (Presser et al., 2014).

Although a more extensive empirical study could be useful to confirm the influence of filter substrate, results suggest that, in addition to taking into account the BC source (fuel and emission process), when calibrating the optical methods it is also necessary to consider the filter substrate.

Table 3 summarizes the calculation and correction equations presented in figures 1 to 3 .

An external verification of the correlations summarized in table 3 would be recommended. In general, the calculation and subsequent testing of these correction coefficients against a reference system is recommended for each specific study, given that each specific population is affected by EC and BC emissions from emission processes, which determine the type of aerosol generated (Bond, 2004) and thus the correction coefficients. Statistical representativeness should also be taken into account.

\section{CONCLUSIONS}

This paper shows that, for the aerosol types and concentrations tested and ensuring that calibration is carried out with local aerosols, optical methods such as reflectometry or a cell-phone based system may constitute low-cost alternatives for the 
estimation of BC or EC concentrations on filter substrates in cookstove studies under resource-constrained conditions.

Prior to the application of either of these techniques, locally-determined correction coefficients must be calculated by comparison with a reference method based on a statistically significant number of samples for each specific study. The calibration should be carried out using filters collected in the field and under the same conditions as will be assessed, given that laboratory conditions will not yield the same type of emissions.

Results highlight the need to take into account the aerosol load on the filter when calibrating the lower cost methods, as well as the filter substrate.

The easy use of the cell-phone system opens up options for its application in science projects which actively involve citizens in scientific endeavours, also known as citizen science. This methodology could be useful for the process of data collection, which would increase the amount and frequency of data being collected, reducing the time and cost of sampling. Moreover, this would facilitate awareness raising regarding the environmental and health issues related to cookstoves and may lead to positive behavioural changes (Wyles et al., 2016).

\section{ACKNOWLEDGEMENTS}

The authors acknowledge the Global Alliance for Clean Cookstoves (GACC, Enhancing Capacity of Regional Testing and Knowledge Centers, RTKC2), the Iberdrola Foundation (Grant for Research on Energy and the Environment), and the Spanish National Research Council (CSIC, I-COOP programme through project COOPB20122) for the financial support provided to carry out this study. The Nexleaf Analytics personnel is acknowledged for their technical support and the referees for their helpful comments. 


\section{REFERENCES}

Adeti, P.J, A., H., 2012. Comparison of Cohen, British and Gagel Method of Approach to the Determination of Black Carbon in Nucleapore and Teflon Filters Using the M43D Smokestain Reflectometer. Elixir Pollut. 52, 11258-11260.

Ahmed, T., Dutkiewicz, V.A., Shareef, A., Tuncel, G., Tuncel, S., Husain, L., 2009. Measurement of black carbon (BC) by an optical method and a thermal-optical method: Intercomparison for four sites. Atmos. Environ. 43, 6305-6311. doi:10.1016/j.atmosenv.2009.09.031

Andreae, M.O., Gelencsér, A., 2006. Black carbon or brown carbon? The nature of light-absorbing carbonaceous aerosols. Atmospheric Chem. Phys. 6, 31313148.

Arora, P., Jain, S., 2015. Estimation of Organic and Elemental Carbon Emitted from Wood Burning in Traditional and Improved Cookstoves Using Controlled Cooking Test. Environ. Sci. Technol. 49, 3958-3965. doi:10.1021/es504012v

Begum, B.A., Biswas, S.K., Hopke, P.K., 2007. Source apportionment of air particulate matter by chemical mass balance $(\mathrm{CMB})$ and comparison with positive matrix factorization (PMF) model. Aerosol Air Qual. Res. 7, 446-468.

Bhattacharya, S.C., Albina, D.O., Salam, P.A., 2002. Emission factors of wood and charcoal-_red cookstoves. Biomass Bioenergy 23, 453 - 469.

Biswas, S.K., Tarafdar, S.A., Islam, A., Khaliquzzaman, M., Tervahattu, H., Kupiainen, K., 2003. Impact of Unleaded Gasoline Introduction on the Concentration of Lead in the Air of Dhaka, Bangladesh. J. Air Waste Manag. Assoc. 53, 13551362. doi:10.1080/10473289.2003.10466299

Bond, T.C., Anderson, T.L., Campbell, D., 1999. Calibration and Intercomparison of Filter-Based Measurements of Visible Light Absorption by Aerosols. Aerosol Sci. Technol. 30, 582-600. doi:10.1080/027868299304435 
Bond, T.C., Bhardwaj, E., Dong, R., Jogani, R., Jung, S., Roden, C., Streets, D.G., Trautmann, N.M., 2007. Historical emissions of black and organic carbon aerosol from energy-related combustion, 1850-2000: HISTORICAL BC/OC EMISSIONS. Glob. Biogeochem. Cycles 21, n/a-n/a. doi:10.1029/2006GB002840

Bond, T.C., Doherty, S.J., Fahey, D.W., Forster, P.M., Berntsen, T., DeAngelo, B.J., Flanner, M.G., Ghan, S., Kärcher, B., Koch, D., Kinne, S., Kondo, Y., Quinn, P.K., Sarofim, M.C., Schultz, M.G., Schulz, M., Venkataraman, C., Zhang, H., Zhang, S., Bellouin, N., Guttikunda, S.K., Hopke, P.K., Jacobson, M.Z., Kaiser, J.W., Klimont, Z., Lohmann, U., Schwarz, J.P., Shindell, D., Storelvmo, T., Warren, S.G., Zender, C.S., 2013. Bounding the role of black carbon in the climate system: A scientific assessment: BLACK CARBON IN THE CLIMATE SYSTEM. J. Geophys. Res. Atmospheres 118, 5380-5552. doi:10.1002/jgrd.50171

Cavalli, F., Viana, M., Yttri, K.E., Genberg, J., Putaud, P., 2010. Toward a standardised thermal-optical protocol for measuring atmospheric organic and elemental carbon: the EUSAAR protocol. Atmospheric Meas. Tech. 3, 79-89. doi:10.5194/amt-3-79-2010

Chow, J.C., Watson, J.G., Chen, L.-W.A., Arnott, W.P., Moosmüller, H., 2004. Equivalence of elemental carbon by thermal/optical reflectance and transmittance with different temperature protocols. Environ. Sci. Technol. 38, 4414-4422. doi:10.1021/es034936u

Davy, P.M., Tremper, A.H., Nicolosi, E.M.G., Quincey, P., Fuller, G.W., 2017. Estimating particulate black carbon concentrations using two offline light absorption methods applied to four types of filter media. Atmos. Environ. 152, 24-33. doi:10.1016/j.atmosenv.2016.12.010

Downward, G.S., Hu, W., Rothman, N., Reiss, B., Wu, G., Wei, F., Xu, J., Seow, W.J., Brunekreef, B., Chapman, R.S., Qing, L., Vermeulen, R., 2015. Outdoor, indoor, 
and personal black carbon exposure from cookstoves burning solid fuels. Indoor Air. doi:10.1111/ina.12255

Edwards, J.D., Ogren, J.A., Weiss, R.E., Charlson, R.J., 1983. Particulate air pollutants: A comparison of British "Smoke" with optical absorption coefficient and elemental carbon concentration. Atmos. Environ. 17. doi:10.1016/00046981(83)90233-0

Fan, C.-W., Zhang, J., 2001. Characterization of emissions from portable household combustion devices: particle size distributions, emission rates and factors, and potential exposures. Atmos. Environ. 35, 1281-1290. doi:10.1016/S13522310(00)00399-X

Hinds, W.C., 1999. Aerosol Technology: Properties, Behavior, and Measurement of Airborne Particles, JOHN WILEY \& SONS, INC. ed. New York.

Huboyo, H.S., Budihardjo, A., Hardyanti, N., 2009. Black carbon concentration in kitchens using fire-wood and kerosene fuels. J Appl Sci Env. Sanit 4, 55-62.

Instructions for Use of the Laboratory Emissions Monitoring System, 2013. . Aprovecho Research Center, Cottage Grove, Oregon.

Jacobson, M.Z., 2000. Strong radiative heating due to the mixing state of black carbon in atmospheric aerosols. Nature 409, 695-697. doi:10.1038/35055518

Johnson, M., Edwards, R., Alatorre Frenk, C., Masera, O., 2008. In-field greenhouse gas emissions from cookstoves in rural Mexican households. Atmos. Environ. 42, 1206-1222. doi:10.1016/j.atmosenv.2007.10.034

Lamarque, J.-F., Bond, T.C., Eyring, V., Granier, C., Heil, A., Klimont, Z., Lee, D., Liousse, C., Mieville, A., Owen, B., Schultz, M.G., Shindell, D., Smith, S.J., Stehfest, E., Van Aardenne, J., Cooper, O.R., Kainuma, M., Mahowald, N., McConnell, J.R., Naik, V., Riahi, K., van Vuuren, D.P., 2010. Historical (18502000) gridded anthropogenic and biomass burning emissions of reactive gases and aerosols: methodology and application. Atmospheric Chem. Phys. 10, 7017-7039. doi:10.5194/acp-10-7017-2010 
MacCarty, N., Ogle, D., Still, D., Bond, T., Roden, C., 2008. A laboratory comparison of the global warming impact of five major types of biomass cooking stoves. Energy Sustain. Dev. 12, 56-65. doi:10.1016/S0973-0826(08)60429-9

MacCarty, N., Ogle, D., Still, D., Bond, T., Roden, C., Willson, B., 2007. Laboratory comparison of the global-warming potential of six categories of biomass cooking stoves. Creswell Aprovecho Res. Cent.

Novakov, T., Corrigan, C., 1995. Influence of Sample Composition on Aerosol Organic and Black Carbon Determinations (No. LBL-37153). California.

Pachauri, R.K., Reisinger, A. (Eds.), 2007. Climate Change 2007: Synthesis Report. Contribution of Working Groups I, II and III to the Fourth Assessment Report of the Intergovernmental Panel on Climate Change. IPCC, Geneva.

Patange, O.S., Ramanathan, N., Rehman, I.H., Tripathi, S.N., Misra, A., Kar, A., Graham, E., Singh, L., Bahadur, R., Ramanathan, V., 2015. Reductions in Indoor Black Carbon Concentrations from Improved Biomass Stoves in Rural India. Environ. Sci. Technol. 49, 4749-4756. doi:10.1021/es506208x

Petzold, A., Ogren, J.A., Fiebig, M., Laj, P., Li, S.-M., Baltensperger, U., Holzer-Popp, T., Kinne, S., Pappalardo, G., Sugimoto, N., Wehrli, C., Wiedensohler, A., Zhang, X.-Y., 2013. Recommendations for reporting "black carbon" measurements. Atmospheric Chem. Phys. 13, 8365-8379. doi:10.5194/acp-138365-2013

Presser, C., Conny, J.M., Nazarian, A., 2014. Filter Material Effects on Particle Absorption Optical Properties. Aerosol Sci. Technol. 48, 515-529. doi:10.1080/02786826.2014.890999

Ramanathan, N., Lukac, M., Ahmed, T., Kar, A., Praveen, P.S., Honles, T., Leong, I., Rehman, I.H., Schauer, J.J., Ramanathan, V., 2011. A cellphone based system for large-scale monitoring of black carbon. Atmos. Environ. 45, 4481-4487. doi:10.1016/j.atmosenv.2011.05.030 
Ramanathan, V., Carmichael, G., 2008. Global and regional climate changes due to black carbon. Nat. Geosci 1, 221-227. doi:10.1038/ngeo156

Rehman, I.H., Ahmed, T., Praveen, P.S., Kar, A., Ramanathan, V., 2011. Black carbon emissions from biomass and fossil fuels in rural India. Atmospheric Chem. Phys. 11, 7289-7299. doi:10.5194/acp-11-7289-2011

Report to Congress on Black Carbon. Appendix 1 (No. EPA-450/R-12-001), 2012. . US EPA, Washington, DC, USA.

Report to Congress on Black Carbon (No. Publication No. EPA-450/R-12-001), 2012. . United States Environmental Protection Agency. Department of the Interior, Environment, and Related Agencies Appropriations Act.

Roden, C.A., Bond, T.C., Conway, S., Osorto Pinel, A.B., MacCarty, N., Still, D., 2009. Laboratory and field investigations of particulate and carbon monoxide emissions from traditional and improved cookstoves. Atmos. Environ. 43, 11701181. doi:10.1016/j.atmosenv.2008.05.041

Safo-Adu, G., Ofosu, F.G., Carboo, D., Armah, Y.S., 2014. Heavy metals and black carbon assessment of PM10 particulates along Accra-Tema highway in Ghana. Int. J. Sci. Technol. 3.

Salako, G.O., 2012. Exploring the Variation between EC and BC in a Variety of Locations. Aerosol Air Qual. Res. doi:10.4209/aaqr.2011.09.0150

StatPoint Technologies, Inc., 2014. Statgraphics Centurion. Warrenton, Virginia.

The Water Boiling Test. Version 4.2.3. Cookstove Emissions and Efficiency in a Controlled Laboratory Setting, Global Alliance for Clean Cookstoves. ed, 2014.

United Nations Environment Programme (Ed.), 2011. Near-term climate protection and clean air benefits: actions for controlling short-lived climate forcers: a UNEP synthesis report. United Nations Environemnt Programme, Nairobi, Kenya.

Venkataraman, C., Habib, G., Eiguren-Fernandez, A., Miguel, A.H., Friedlander, S.K., 2005. Residential Biofuels in South Asia: Carbonaceous Aerosol Emissions and Climate Impacts. Science 307, 1454-1456. doi:10.1126/science.1104359 
Watson, J.G., Chow, J.C., Chen, L.-W.A., 2005. Summary of Organic and Elemental Carbon/Black Carbon Analysis Methods and Intercomparisons. Aerosol Air Qual. Res. 5, 65-102.

Weingartner, E., Saathoff, H., Schnaiter, M., Streit, N., Bitnar, B., Baltensperger, U., 2003. Absorption of light by soot particles: determination of the absorption coefficient by means of aethalometers. J. Aerosol Sci. 34, 1445-1463. doi:10.1016/S0021-8502(03)00359-8

WHO, Scovronik, N., 2015. Reducing global health risks through mitigation of shortlived climate pollutants. Scoping report for policymakers. WHO, Switzerland.

Woolson, R.F., 2008. Wilcoxon Signed-Rank Test. Wiley Encycl. Clin. Trials 1-3.

Wyles, K.J., Pahl, S., Holland, M., Thompson, R.C., 2016. Can Beach Cleans Do More Than Clean-Up Litter? Comparing Beach Cleans to Other Coastal Activities. Environ. Behav. 13916516649412.

Yan, B., Kennedy, D., Miller, R.L., Cowin, J.P., Jung, K., Perzanowski, M., Balleta, M., Perera, F.P., Kinney, P.L., Chillrud, S.N., 2011. Validating a nondestructive optical method for apportioning colored particulate matter into black carbon and additional components. Atmos. Environ. 45, 7478-7486. doi:10.1016/j.atmosenv.2011.01.044

Zanatta, M., Gysel, M., Bukowiecki, N., Müller, T., Weingartner, E., Areskoug, H., Fiebig, M., Yttri, K.E., Mihalopoulos, N., Kouvarakis, G., Beddows, D., Harrison, R.M., Cavalli, F., Putaud, J.P., Spindler, G., Wiedensohler, A., Alastuey, A., Pandolfi, M., Sellegri, K., Swietlicki, E., Jaffrezo, J.L., Baltensperger, U., Laj, P., 2016. A European aerosol phenomenology-5: Climatology of black carbon optical properties at 9 regional background sites across Europe. Atmos. Environ. 145, 346-364. doi:10.1016/j.atmosenv.2016.09.035

Zhang, J., Smith, K.R., Ma, Y., Ye, S., Jiang, F., Qi, W., Liu, P., Khalil, M.A.K., Rasmussen, R.A., Thorneloe, S.A., 2000. Greenhouse gases and other 
airborne pollutants from household stoves in China: a database for emission factors. Atmos. Environ. 34, 4537-4549.

\section{Figure Captions:}

-Figure 1. BC determinations $(\mu \mathrm{g} / \mathrm{cm} 2)$ by Nexleaf plotted against EC loads $(\mu \mathrm{g} / \mathrm{cm} 2)$ by TOT.

-Figure 2. EC load $(\mu \mathrm{g} / \mathrm{cm} 2)$ determined by TOT plotted against reflectance readings from the smoke stain reflectometer

-Figure 3. Comparison of $\mathrm{BC}$ concentrations determined by the reflectometer (right) and Nexleaf system (left) on quartz filters and co-located glass fibre filters.

-Figure 4. Testing of correction coefficients and calculation equations obtained.

\section{Figures:}

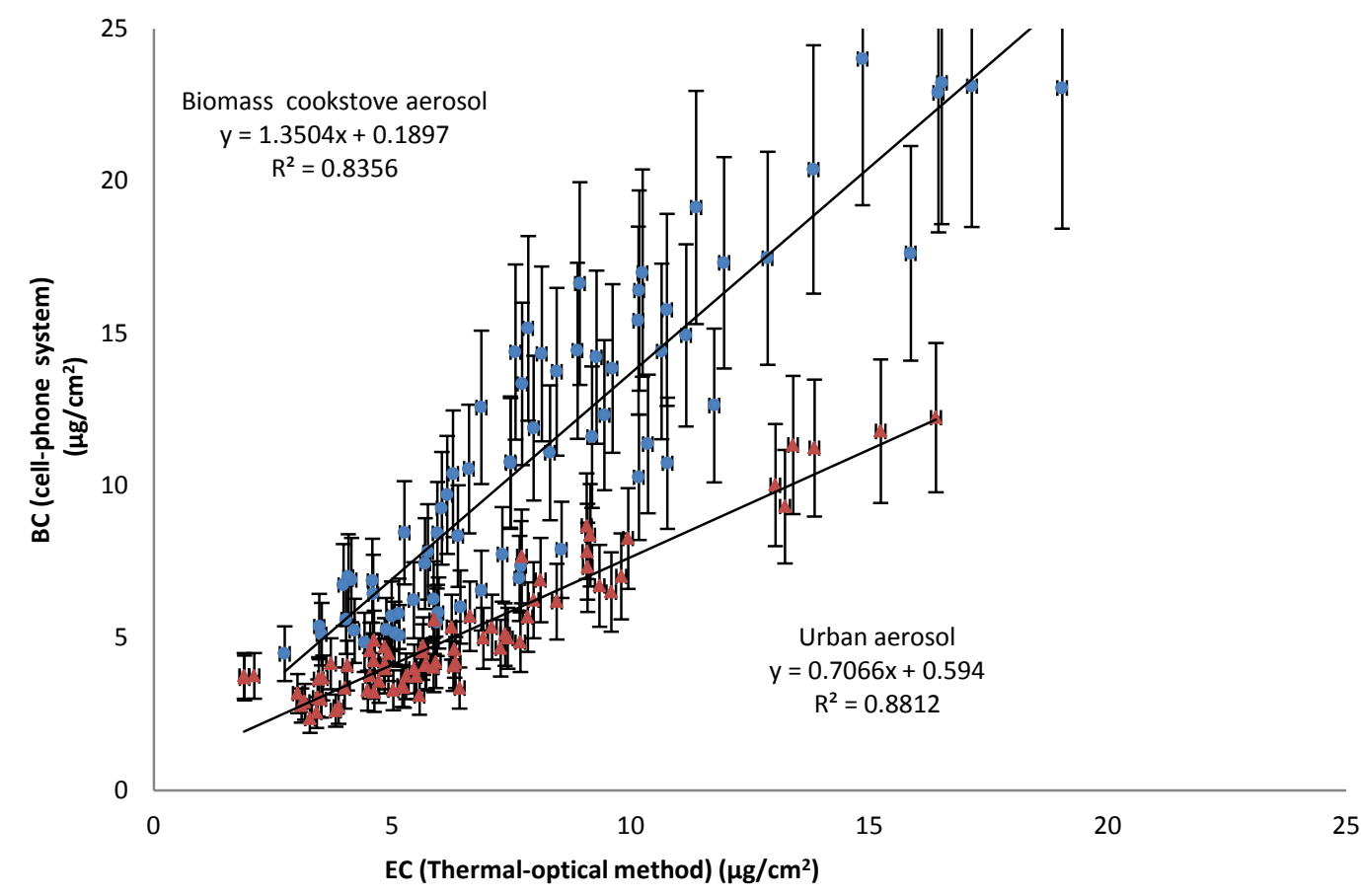

Figure 1 


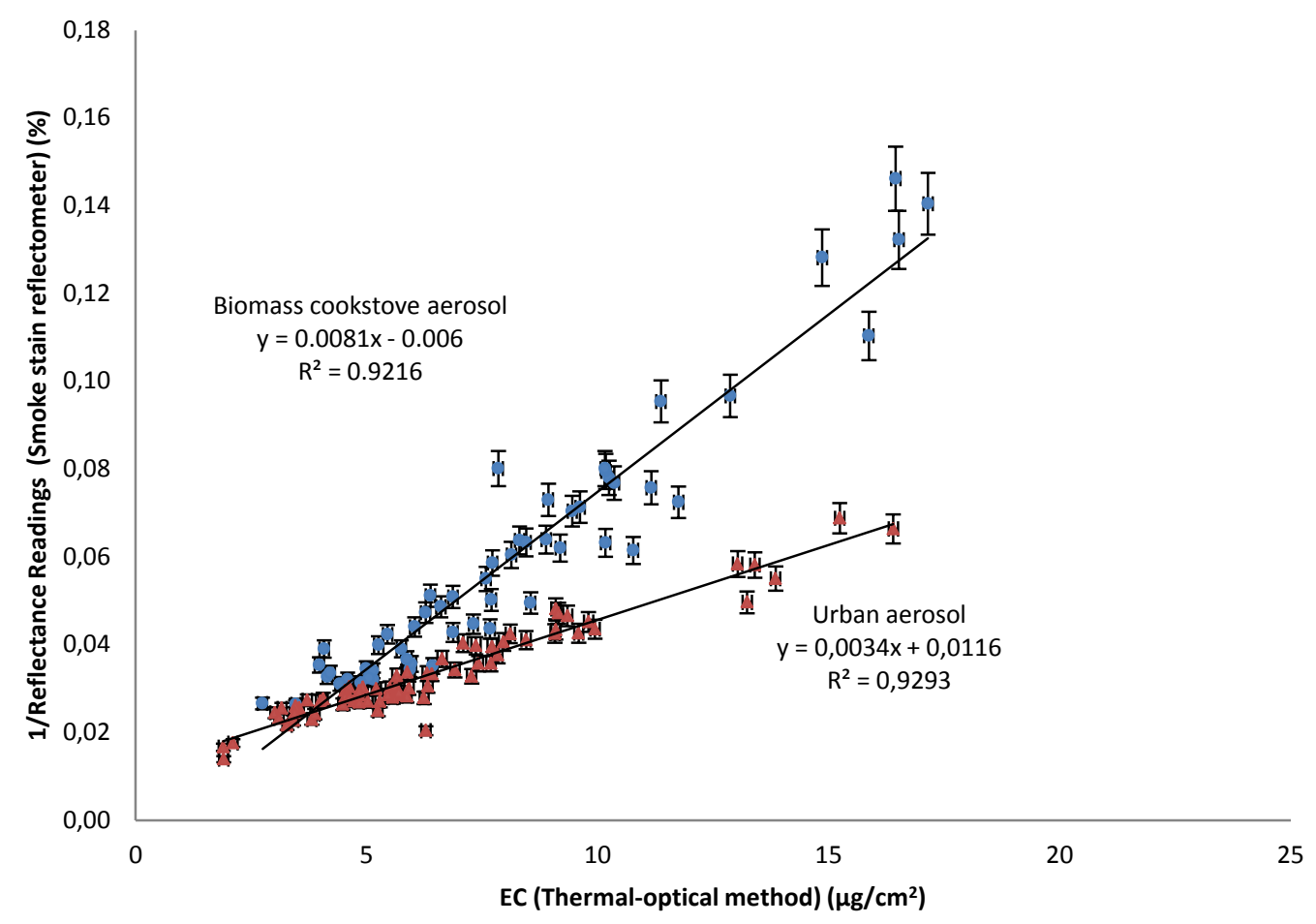

Figure 2
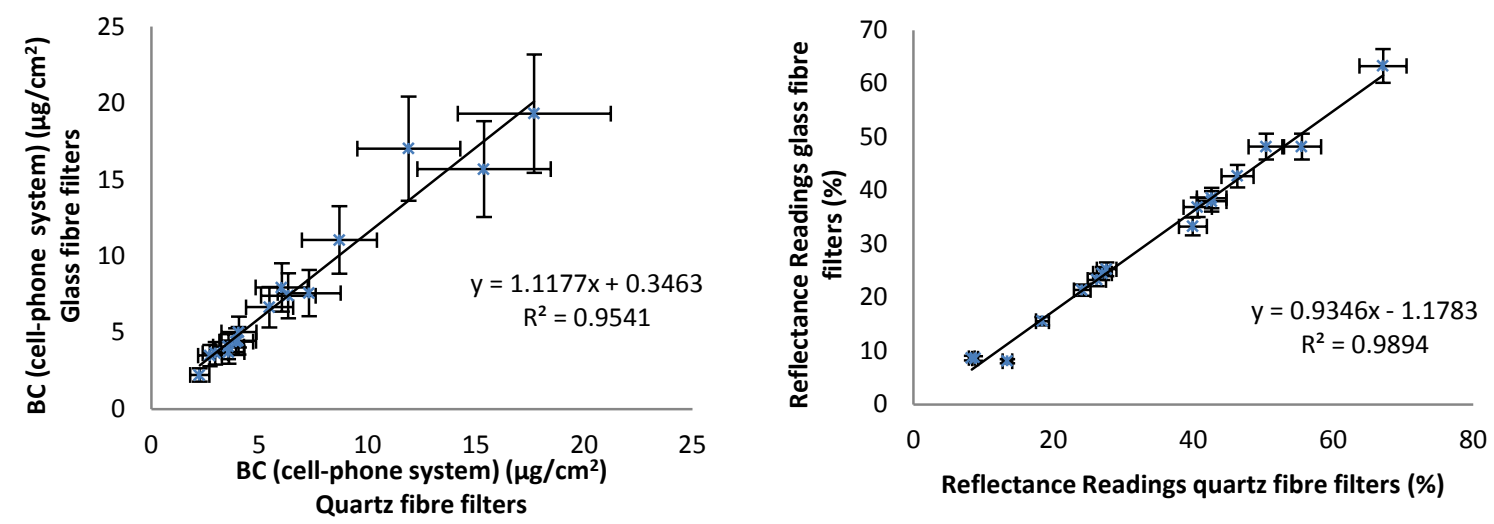

Figure 3 


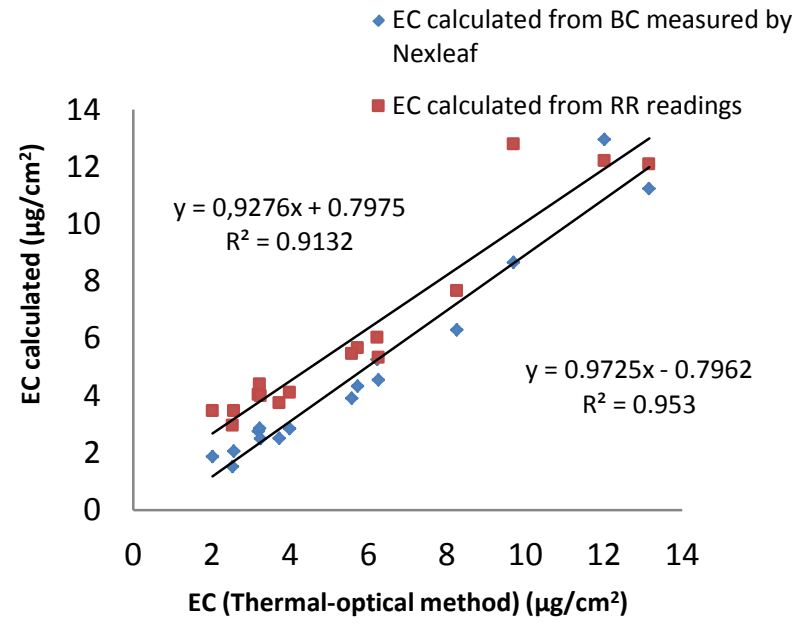

Figure 4 


\section{Tables:}

Table 1. Technical requirements and features of the methods evaluated during the intercomparison.

\begin{tabular}{|c|c|c|c|c|c|c|c|}
\hline Method & Robustness & $\begin{array}{l}\text { Difficult } \\
\text { y of use }\end{array}$ & $\begin{array}{l}\text { Requires a } \\
\text { computer } \\
\text { for } \\
\text { operation }\end{array}$ & $\begin{array}{l}\text { May } \\
\text { operate on } \\
\text { battery }\end{array}$ & $\begin{array}{l}\text { Types of filter } \\
\text { applicable }\end{array}$ & $\begin{array}{l}\text { Accuracy } \\
\text { (according to } \\
\text { manufacturers) }\end{array}$ & Price* $^{\star}$ \\
\hline $\begin{array}{l}\text { Cell-phone } \\
\text { based } \\
\text { system } \\
\text { (Nexleaf) }\end{array}$ & $\begin{array}{l}\text { High (only } \\
\text { requires } \\
\text { normal } \\
\text { maintenanc } \\
\text { e of a cell- } \\
\text { phone or a } \\
\text { camera) }\end{array}$ & Low & $\begin{array}{l}\text { Yes, or a } \\
\text { smartphon } \\
\text { e, both } \\
\text { with } \\
\text { internet } \\
\text { access }\end{array}$ & Yes & $\begin{array}{l}\text { Paper, teflon, } \\
\text { glass fibre, } \\
\text { quartz fibre }\end{array}$ & $\begin{array}{l}\text { Low-Medium } \\
\text { (20\% agreement } \\
\text { with thermos- } \\
\text { optical } \\
\text { method)(Ramanath } \\
\text { an et al., 2011) }\end{array}$ & $\begin{array}{l}\text { Card } \\
\text { with } \\
\text { referenc } \\
\text { e scale } \\
\text { (free) } \\
2 \\
\text { euro/filt } \\
\text { er } \\
\text { analyze } \\
\text { d } \\
\text { Cell- } \\
\text { phone } \\
\text { costs }\end{array}$ \\
\hline $\begin{array}{l}\text { Smoke } \\
\text { Stain } \\
\text { Reflectomet } \\
\text { er (Model } \\
\text { 43D, } \\
\text { Diffusion } \\
\text { Systems } \\
\text { Ltd.) }\end{array}$ & $\begin{array}{l}\text { Medium } \\
\text { (requires } \\
\text { easy } \\
\text { maintenanc } \\
\text { e, cleaning) }\end{array}$ & $\begin{array}{l}\text { Mediu } \\
\mathrm{m}\end{array}$ & $\begin{array}{l}\text { No, } \\
\text { device } \\
\text { readings } \\
\text { are } \\
\text { displayed } \\
\text { in the } \\
\text { screen }\end{array}$ & $\begin{array}{l}\text { No. } \\
\text { Power } \\
\text { requirement } \\
\text { s: 110- } \\
230 \mathrm{VAC} \\
50 / 60 \mathrm{HZ}\end{array}$ & $\begin{array}{l}\text { Paper } \\
\text { (recommend } \\
\text { ed by the } \\
\text { manufacture } \\
\text { d), teflon, } \\
\text { glass fibre } \\
\text { and quartz } \\
\text { fibre filters }\end{array}$ & $\begin{array}{l}\text { Medium-High } \\
5 \%{ }^{39}\end{array}$ & $\begin{array}{l}<4.000 \\
\text { euros } \\
\text { (approx) }\end{array}$ \\
\hline $\begin{array}{l}\text { Sunset } \\
\text { Laboratory } \\
\text { Carbon } \\
\text { Analyzer }\end{array}$ & $\begin{array}{l}\text { Medium- } \\
\text { Low } \\
\text { (requires } \\
\text { frequent } \\
\text { maintenanc } \\
\text { e, } \\
\text { laboratory- } \\
\text { based) }\end{array}$ & $\begin{array}{l}\text { Mediu } \\
\text { m-High }\end{array}$ & Yes & $\begin{array}{l}\text { No. } \\
\text { Power } \\
\text { requirement } \\
\mathrm{s}: \\
110- \\
230 \mathrm{VAC} \\
50 / 60 \mathrm{HZ}\end{array}$ & $\begin{array}{l}\text { Quartz fibre } \\
\text { filters }\end{array}$ & $\begin{array}{l}\text { High } \\
\left( \pm 0,1 \quad \mu \mathrm{g} / \mathrm{cm}^{2} \text { for }\right. \\
\text { EC) }\end{array}$ & $\begin{array}{l}>40.000 \\
\text { euros } \\
\text { (approx) }\end{array}$ \\
\hline
\end{tabular}


2 Table 2. Wilcoxon test results $(p<0.05)$ and absolute value relative difference between

3 results from the Nexleaf system and TOT, as a function of aerosol type and EC load. N

4 =number of samples, Z=test statistic. *Statistically significantly differences

5

6

7

8

\begin{tabular}{|c|c|c|}
\hline \multirow{2}{*}{$\begin{array}{c}\mathrm{EC}(\mathrm{BC}) \\
\text { micrograms } / \mathrm{cm}^{2}\end{array}$} & \multicolumn{2}{|c|}{ Absolute value relative differences } \\
\hline & $\begin{array}{c}\text { Biomass } \\
\text { cookstove aerosol }\end{array}$ & Urban aerosol \\
\hline 1 to $5(\mathrm{~N}=13)$ & $43 \% *(Z=3.146)$ & $23 \%(Z=1.470)$ \\
\hline 5 to $10(\mathrm{~N}=40)$ & $40 \% *(Z=4.631)$ & $26 \%$ * $(Z=5.520)$ \\
\hline 10 to $20(\mathrm{~N}=20)$ & $36 \% *(Z=3.864)$ & $23 \% *(Z=2.097)$ \\
\hline
\end{tabular}

9

10

11 Table 3: Summary of the correction equations obtained as a functionof analytical 12 method, aerosol and filter type. BC and EC in $\mu \mathrm{g} / \mathrm{cm} 2 ; \mathrm{RR}=$ Reflectance readings in \%.

\begin{tabular}{|c|c|c|c|c|}
\hline \multirow{3}{*}{$\begin{array}{l}\text { Correction equation } \\
\text { (TOT vs Optical } \\
\text { method with quartz } \\
\text { fibre filters) }\end{array}$} & \multicolumn{2}{|c|}{ Cell-phone system } & \multicolumn{2}{|c|}{ Smoke stain reflectometer } \\
\hline & $\begin{array}{c}\text { Biomass cookstove } \\
\text { aerosol }\end{array}$ & Urban aerosol & $\begin{array}{c}\text { Biomass cookstove } \\
\text { aerosol }\end{array}$ & Urban aerosol \\
\hline & $\begin{array}{c}\mathrm{BC}=1.3504 \mathrm{EC}+0.1897 \\
\mathrm{R}^{2}=0.8356\end{array}$ & $\begin{array}{c}B C=0.7066 E C+0.594 \\
R^{2}=0.8812\end{array}$ & $\begin{array}{c}1 / \mathrm{RR}=0.0081 \mathrm{EC}-0.006 \\
\mathrm{R}^{2}=0.9216\end{array}$ & $\begin{array}{c}1 / \mathrm{RR}=0.0034 \mathrm{EC}+0.0116 \\
\mathrm{R}^{2}=0.9293\end{array}$ \\
\hline $\begin{array}{c}\text { Filter material } \\
\text { adjustment (quartz- } \\
\text { glass fibre) }\end{array}$ & \multicolumn{2}{|c|}{$\begin{array}{c}\text { BCglass = 1.1177BCquartz }+0.3463 \\
R^{2}=0.9541\end{array}$} & \multicolumn{2}{|c|}{$\begin{array}{c}\text { RRglass }=0.9346 \text { Rquartz }-1.1783 \\
R^{2}=0.9894\end{array}$} \\
\hline
\end{tabular}




\section{SUPPLEMENTARY MATERIAL FOR:}

Intercomparison of methods to estimate black carbon emissions from cookstoves

Candela de la Sota ${ }^{1 \star}$, Moustapha Kane ${ }^{2}$, Javier Mazorra ${ }^{1}$, Julio Lumbreras ${ }^{1}$, Issakha Youm $^{2}$, Mar Viana $^{3}$

*Corresponding Author

Contact information for Corresponding Author:

Phone: +34 699284386

E-mail: candela.delasota@upm.es

${ }^{1}$ Technical University of Madrid, José Gutiérrez Abascal, 2, 28006, Madrid, Spain.

${ }^{2}$ Centre for Studies and Research on Renewable Energy (CERER) of the Cheikh Anta Diop University of Dakar(UCAD), Route du Service géographique (HB-87) x HB-478, Hann Bel-Air, 476 Dakar, Senegal.

${ }^{3}$ Institute for Environmental Assessment and Water Research, Spanish National Research Council (IDAEA-CSIC), Jordi Girona 18-26, 08034, Barcelona.

\section{Contents:}

6 Total Pages

Number of figures: 7

Figure S1-Pictures of the Laboratory Emission Monitoring System (LEMS) designed by the Aprovecho Research Centre.

Figure S2 -Schematic of the gravimetric system of the LEMS.

Figure S3- Nexleaf BC reference card.

Figure S4 and S5 - Quartz fiber filters Pallflex, tissuquartz, 2500 QAT-UP.

Figure S6 and S7 - Glass fiber filters Hi-Q environmental products, FPAE-102, $0.3 \mu \mathrm{m}$ aerodynamic equivalent diameter.

Text 1. ANOVA results of the comparison of the regression lines (BC by Nexleaf system vs EC by TOT) for each type of aerosol (biomass cookstove and urban). 


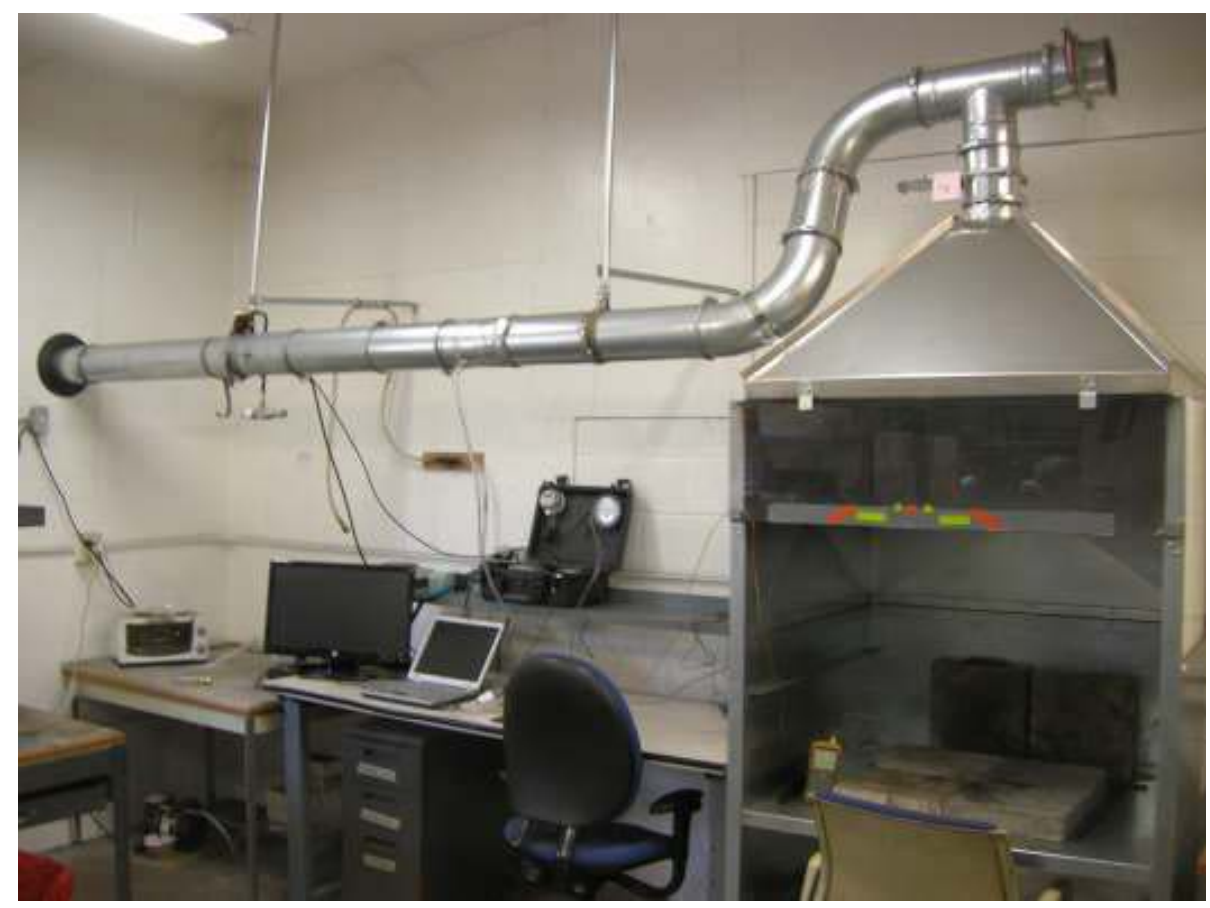

Figure S1-Pictures of the Laboratory Emission Monitoring System (LEMS), designed by the Aprovecho Research Centre.

Reference: Instructions for Use of the Laboratory Emissions Monitoring System; Aprovecho Research Center: Cottage Grove, Oregon, 2013.

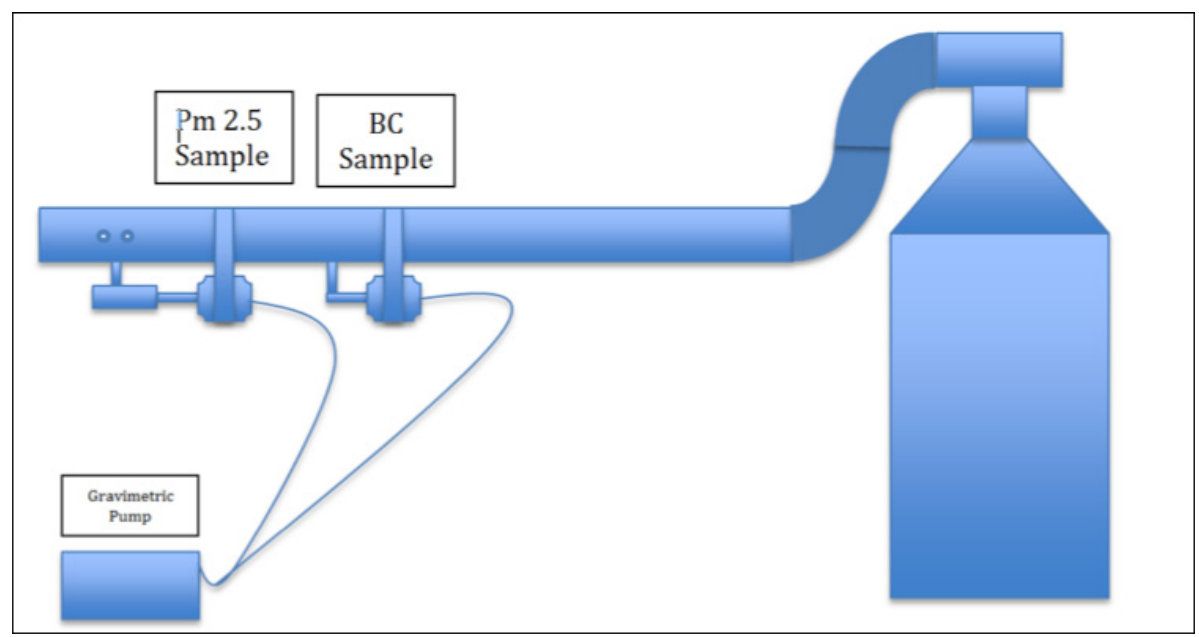

Figure S2-Schematic of the gravimetric system of the LEMS.

Reference: Aprovecho Research Center. http://aprovecho.org/cleaner-burningtechnologies/black-carbon-add-arc-emissions-monitoring-system/ (accessed Aug 18, 2016). 


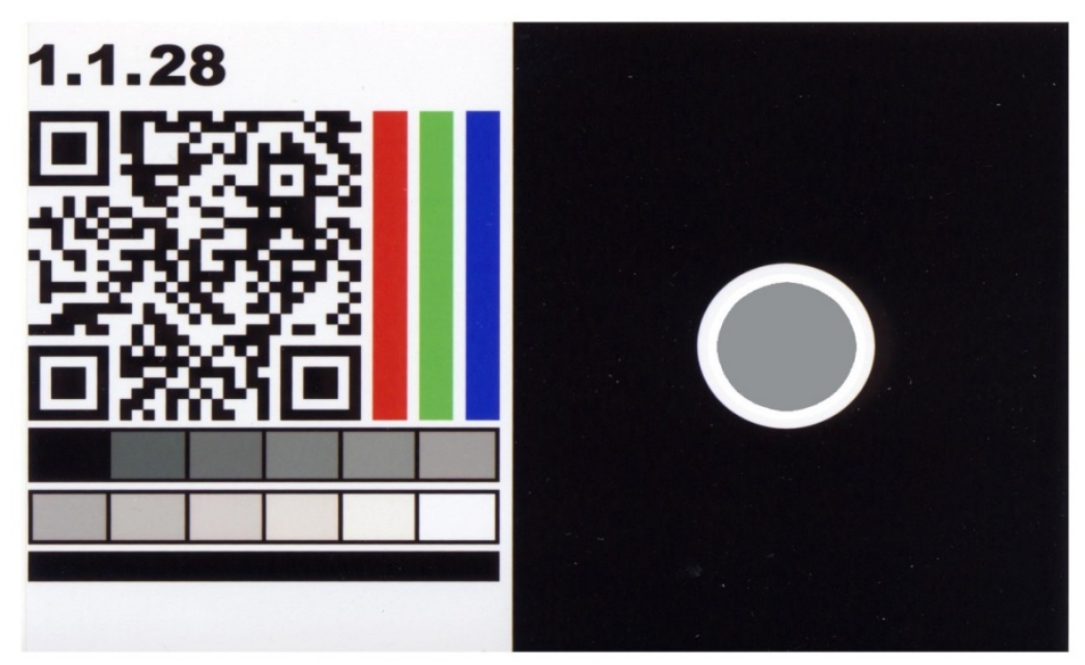

Figure S3- Nexleaf BC reference card.
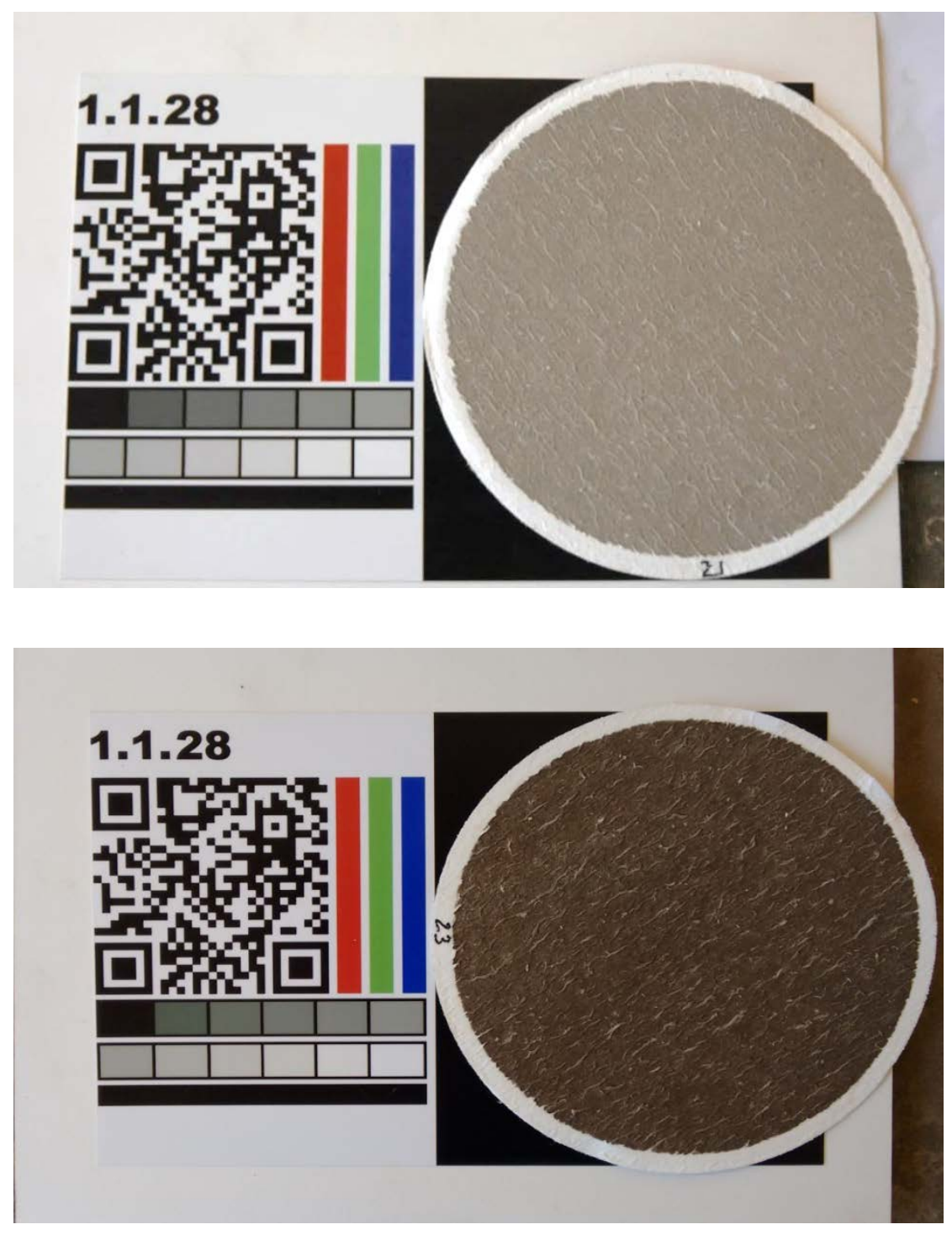

Figure S4 and S5 - Quartz fibre filters Pallflex, tissuquartz, 2500 QAT-UP 

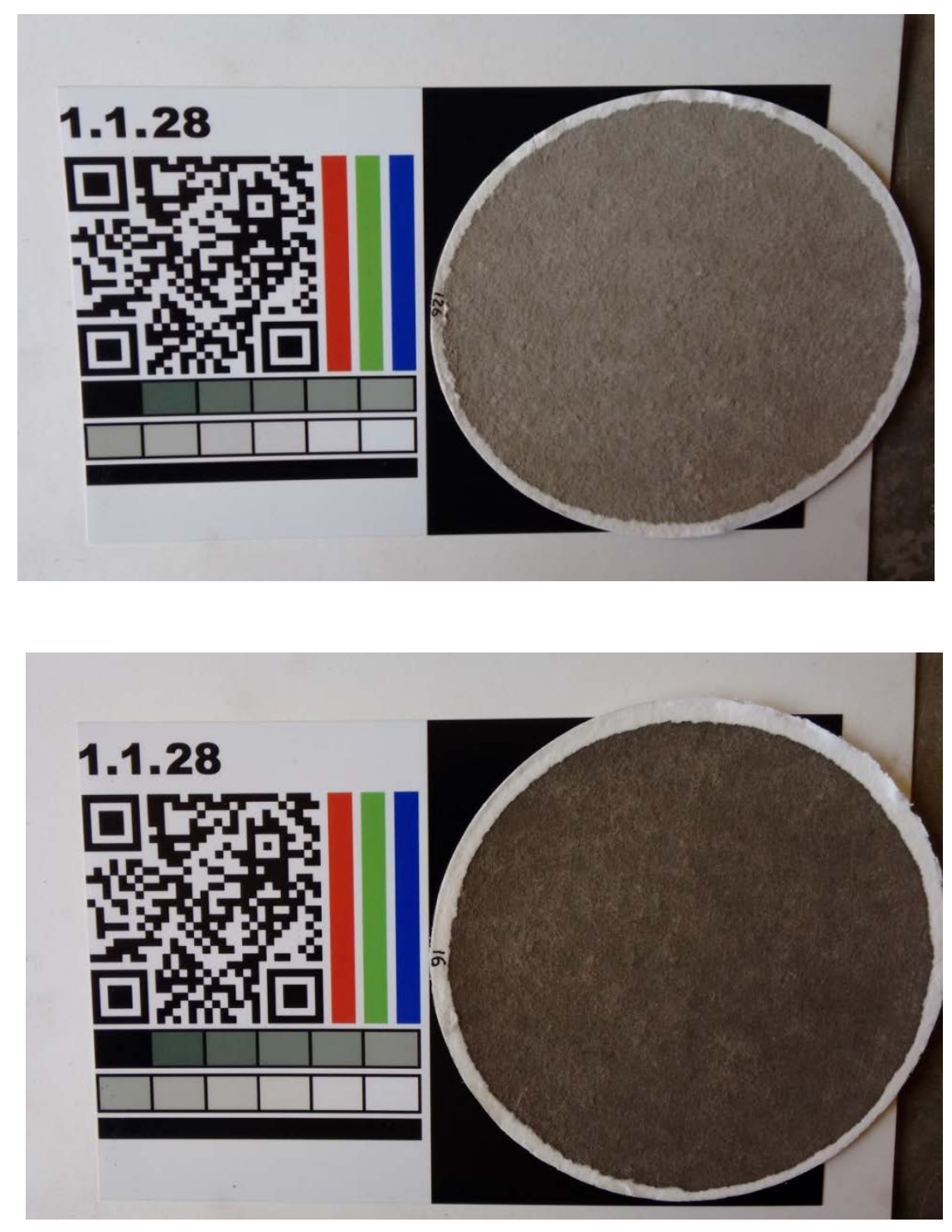

Figure S6 and S7 - Glass fiber filters Hi-Q environmental products, FPAE-102, 0.3 $\mu \mathrm{m}$ aerodynamic equivalent diameter 
Text 1. ANOVA results of the comparison of the regression lines (BC by Nexleaf system vs EC by TOT) for each type of aerosol (biomass cookstove and urban)

Dependent Variable: BC (Nexleaf system) $(Y)$

Independent Variable: EC (Thermal-optical method) $(X)$

Level codes: Aerosol type

Number of complete cases: 144

Number of regression lines: 2

\section{Multiple regression analysis}

\begin{tabular}{|l|l|l|l|l|}
\hline & & Standard & $T$ & \\
\hline Parameter & Estimate & Error & Statistic & $P$-value \\
\hline CONSTANT & 0,409443 & 0,325354 & 1,25845 & 0,2103 \\
\hline EC (Thermal-optical method) (X) & 0,730079 & 0,049356 & 14,7921 & 0,0000 \\
\hline $\begin{array}{l}\text { EC (Thermal-optical method) *Aerosol } \\
\text { type=Biomass cookstove }\end{array}$ & 0,597796 & 0,0354235 & 16,8757 & 0,0000 \\
\hline
\end{tabular}

\section{Coefficients}

\begin{tabular}{|l|l|l|}
\hline Aerosol type & Intercept & Slope \\
\hline Urban & 0,409443 & 0,730079 \\
\hline Biomass cookstove & 0,409443 & 1,32788 \\
\hline
\end{tabular}

Analysis of Variance

\begin{tabular}{|l|l|l|l|l|l|}
\hline Source & Sum of Squares & Df & Mean Square & F-ratio & P-value \\
\hline Model & 3343,85 & 2 & 1671,93 & 631,10 & 0,0000 \\
\hline Residual & 373,541 & 141 & 2,64923 & & \\
\hline Total (Corr.) & 3717,4 & 143 & & & \\
\hline
\end{tabular}

R-Squared $=89,9515$ percent

R-Squared (adjusted for d.f) $=89,809$ porciento

Standard Error of Est. $=1,62765$

Mean absolute error $=1,18104$

Durbin-Watson Statistic $=1,30403(P=0,0000)$

Lag 1 residual autocorrelation $=0,344655$

Residual Analysis

\begin{tabular}{|l|l|l|}
\hline & Estimation & Validation \\
\hline $\mathrm{n}$ & 144 & \\
\hline MSE & 2,64923 & \\
\hline MAE & 1,18104 & \\
\hline MAPE & 16,1174 & \\
\hline ME & $7,83632 E-15$ & \\
\hline MPE & $-3,01055$ & \\
\hline
\end{tabular}

Further ANOVA for Variables in the Order Fitted

\begin{tabular}{|l|l|l|l|l|l|}
\hline Source & $\begin{array}{l}\text { Sum of } \\
\text { squares }\end{array}$ & Df & Mean Square & F-ratio & P-value \\
\hline $\begin{array}{l}\text { EC (Thermal-optical method) } \\
(\mathrm{X})\end{array}$ & 2589,38 & 1 & 2589,38 & 977,41 & 0,0000 \\
\hline Slopes & 754,473 & 1 & 754,473 & 284,79 & 0,0000 \\
\hline Model & 3343,85 & 2 & & & \\
\hline
\end{tabular}

